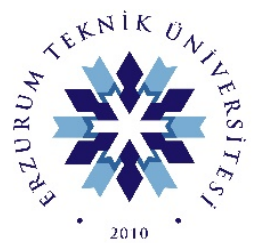

\title{
BİRİNCİ DÜNYA SAVAŞI'NDA KÖPRÜKÖY VE AZAP ZAFERLERİ
} KOPRUKOY AND AZAP VICTORIES IN THE FIRST WORLD WAR

\section{GÜRAY ALPAR}

\author{
Doktor, Araştırmacı Yazar \\ akadem2010@yahoo.com
}

ETÜ Sosyal Bilimler Enstitüsü Dergisi | ETU Journal of Social Sciences Institute

III/6, Ekim | October 2018, Erzurum

ISSN: 2149-939X

$\begin{array}{ll}\text { Makale Türü | Article Types } & : \text { Araştırma Makalesi | Research Article } \\ \text { Geliş Tarihi | Received Date } & : 10.07 .2018 \\ \text { Kabul Tarihi | Accepted Date } & : \text { 17.08.2018 } \\ \text { Sayfa | Pages } & : \text { 97-119 } \\ \text { DOI- } & : \text { http://dx.doi.org/10.29157/etusbe.69 }\end{array}$




\title{
BİRINCII DÜNYA SAVAŞI'NDA KÖPRÜKÖY VE AZAP ZAFERLERİ
}

\author{
Güray ALPAR
}

ETÜSosyal Bilimler Enstitüsü Dergisi (ETÜSBED), C.III S.6, Ekim 2018, Sayfa:97-119

\section{ÖZET}

Tarihçinin görevi doğruyu doğru olmayandan ayırarak, doğru olanları bir düzen içinde bir araya getirmektir. Eğer tarihçi olayları bir şekilde analiz etmeden, iyice anlamadan olduğu gibi birleştirip naklederse olayların önünde kaybolur gider. Her durumda olayları birbirinden ayırıp gerçeği ortaya çıkarmak gerekir. Bu kapsamda Birinci Dünya Savaşı́nın hemen başlangıcında gerçekleşen Köprüköy ve Azap Muharebeleri ve bu muharebeler esnasında Türk Ordusunun kazandığı zaferler yeterince ortaya çıkmamış gözükmektedir. Bunda hemen sonrasında gerçekleştirilen Sarıkamış Harekâtının yarattığı üzüntünün büyük payı olduğu bir gerçektir. Birinci Dünya Savaşının hemen başlangıcında, Osmanlı hudut birliklerinin Rus ilerleyişi başlar başlamaz süratli bir şekilde geri çekilmesi, atılganlığıyla meşhur Rus General Bergman tarafından ciddi bir fırsat olarak algılandığından, 4 Kasım 1914 tarihinde Rus Ordusu önce Horasan daha sonra Köprüköy bölgesine kadar ilerledi. Bu esnada Enver Paşa'nın ikazı sonucu isteksiz bir şekilde harekete geçen III. Ordu Komutanı Hasan İzzet Paşa, Rus birliklerine 6 Kasım'da Köprüköy'de karşı taarruz icra ederek, sadece onları durdurmakla kalmadı Bergman'ı yenilgiye de uğrattı. Bu durum Osmanlı Ordusu için büyük bir fırsat yaratmıştı ancak daha sonra Horasan istikametinde yapılan taarruzlarda Ordu birlikleri bir bütün halinde kullanılmak yerine parça parça hareket ettirildiğinden Rusların tamamen imha edilmesi fırsatı kaçırıldı. Eğer Köprüköy ve Horasan bölgesinde icra edilen harekât başarılı olsaydı belki de Sarıkamış Harekâtına gerek kalmayacak ve tarihin seyri daha başlangıçta değişebilecekti. Bu zaferler kazanılırken Erzurum ve civarındaki halk büyük fedakârlıklarda bulunmuş, erzak ve cephaneyi cepheye mektepli çocuklarla taşımış, bu çocukların bir kısmı yollarda donmuştur. Yine bu bölgeden oluşturulan aşiret alayları ordu ile birlikte savaşarak zaferlerin kazanılmasına katkıda bulunmuşlardır. Bu savaşlarda büyük kahramanlık gösteren Albay Ziya YERGÖK'ün "Allah uzun süreden beri ilk defa bizlere Rusları kaçarken arkalarından seyretmeyi nasip etti." dediği bu muharebelerde kazanılan başarılar sonucu Ruslar, Horasan' da Aras Nehri civarında savunmaya geçmişlerdir. Köprüköy ve Azap Muharebelerinde zor şartlar altında kazanılan zaferlerin ortaya çıkarılarak gelecek nesillere aktarılmasının önemli olduğu düşünülmektedir..

Anahtar Kelimeler: Köprüköy, Azap, I.Dünya Savaşı, Köprüköy ve Azap Zaferleri. 


\section{KOPRUKOY AND AZAP VICTORIES IN THE FIRST WORLD WAR}

\section{ABSTRACT}

The task of the historian is to find the truth and to bring the right things together in order. The historian should understand and combine events by analyzing in a good way. For this reason, it is necessary to separate events from each other and reveal the truth. In this context, the victories of the Turkish Army in Koprukoy and Azap Battles which took place at the very beginning of the First World War and look like kept in the background. It is estimated that the sadness created by Sarikamis Operation, which was carried out immediately afterwards, has a big share.

At the very beginning of the First World War, the rapid withdrawal of the Ottoman border troops from the beginning of the Russian advance had been perceived as a serious opportunity by the famous Russian General Bergman. On November 4, 1914, the Russian army first advanced to Horasan and then to the Koprukoy region. III. Army Commander Hasan Izzet, who acts with the warning by Enver Pasha, attacked Russian troops on November 6th at Koprukoy at this time. Not only did he stop them, but he also defeated Bergman. This created a great opportunity for the Ottoman Army, but later on the attacks in the direction of Horasan, the army units were moved in pieces instead of being used as a whole, so the opportunity to completely destroy the Russians was abducted. If the operation carried out in the Koprukoy and Horasan regions was successful, perhaps it would not be necessary for the Sarikamis Operation and the history would change at the beginning.

While these victories were being won, the Erzurum region people made great sacrifices. They carried the supplies and ammunition and some of these children froze to death in ways. The tribal regiments formed in this region also contributed to the victory by fighting with the army. Colonel Ziya Yergok, who shows great heroism in these wars, had said that "Allah gave us a pleasure of watching the Russians behind their backs for the first time since a long time." The Russians had been defended around Aras River in Horasan after the result of the successes achieved in these battles. It is important that the victories under difficult conditions in Koprukoy and Azap Battles are revealed and transferred to future generations.

Keywords: Koprukoy, Azap, The First World War, Koprukoy and Azap Victories.. 


\section{Giriş}

Erzurum ve çevresi, bölge üzerinde büyük beklenti ve politikaları olan Rusya için de önemli bir konumda yer almış, Rusya'nın güneye iniş istikametindeki ana hedeflerinin en önemlilerinden birisini teşkil etmiştir. Birinci Dünya Savaşı'nın hemen başlangıcında Erzurum'da gerçekleşen Köprüköy ve Azap Muharebeleri ve bu muharebeler esnasında Türk Ordusunun kazandığı zaferler, hemen sonrasında yaşanan Sarıkamış felaketi nedeniyle gölgede kalmıştır. Günümüzde bu savaşlar değişik kaynaklarda değişik şekilde anlatılmakta ve farklı anlatımlar muharebelerin seyri ile ilgili kafalarda karışıklıklar yaratmaktadır. Tarihçinin görevi doğruyu doğru olmayandan ayırarak gerçeği ortaya çıkarmaktır. Bu çalışmada Sarıkamış öncesinde yaşanan bu muharebelerin değissik kaynaklardan yararlanılarak gerçeğin mümkün olduğunca ortaya konulması hedeflenmektedir.

Birinci Dünya Savaşı öncesi belirgin bir "Türk Strateji"sinden bahsetmek mümkün değildi. Stratejik tercihler Alman önceliklerine göre yapılmış, savaş için gerekli silah ve cephane umutları Almanlara bağlanmıştı. ${ }^{1}$ Yine de bu dünya savaşında en fazla şaşırtan taraflardan birisi Osmanlılar olmuştur. Öyle ki 1912 1913 yıllarında gerçekleşen Balkan Savaşlarında yeni kurulan zayıf Balkan Devletlerine yenilmiş bir ordu, yapılan düzenlemelerle dünya savaşı öncesi önemli ölçüde ilerleme kaydetmiştir. Çalışmalar sonucu Çağdaş Avrupa Ordularıla aynı düzenlemeler yapılmış, hatta bazı yönlerden onların bile önüne geçilmiştir. ${ }^{2} \mathrm{Bu}$ düzenlemelerde direk topçu ateşi ile desteklenen taarruz esas alınmıştı. Bu noktada Avrupalılar gibi kolordu kuruluşu benimsenmiş ancak Avrupa'dakiler gibi iki değil, üç tümenli kolordu kuruluşu esas alınarak bir adım ileri geçilmiştir. Buna göre her kolorduda yaklaşık 40 bin asker olacaktı. Tatbikatlarla denenen bu kuruluşun, hantal Avrupa orduları kuruluşuna göre daha esnek ve uygulanabilir olduğu görülecek ve onlar da Türklerle aynı kuruluşa geçecekti. ${ }^{3}$ Yapılan düzenlemeler sonucu Osmanlı Ordusunda öyle hızlı ilerlemeler görüldü ki, Balkan savaşının o disiplinsiz ordusu, Birinci Dünya Savaşı öncesi Prusya ordusuyla bile kıyaslanacak düzeye gelmişti. ${ }^{4}$

Kazım Karabekir hatıralarında Birinci Dünya Savaşı öncesi ordunun halini iyi görmediğini yazmıştı. Ona göre üst rütbeli komutanların çoğunun yaşı geçmiş, idarenin uygulamaları altında ezilmişlerdi. ${ }^{5}$ Dünya Savaşı öncesi 3 Ocak 1914 tarihinde Genelkurmay Başkanlığına Enver Paşa getirilmişti. Enver Paşa modernizasyona engel olacakları düşüncesi ile 1300 yaşlı subayı emekliye

\footnotetext{
${ }^{1}$ Mehmet Tanju Akad, Osmanlıların Stratejik Sorunları, Kastaş Yayınları, İstanbul, 2005.s.270.

${ }^{2}$ Güray Alpar, Strateji ve Savaş Kültürünün Gelişimi, Pelit Matbaası, Konya, 2015.s.271.

${ }^{3}$ Eward J. Erickson, I. Dünya Savaşında Osmanlı Ordusu, Çev. Kerim Bağrıaçık, Türkiye İş Bankası

Yayınları, İstanbul, 2009. s.278.

${ }^{4}$ Erickson, I. Dünya Savașında Osmanlı Ordusu, s.17-20.

${ }^{5}$ Kazım Karabekir, Hayatım, Yapı Kredi Yayınları, İstanbul, Mart 2017.s.155.
} 
ayırd1. 14 Mart 1914 tarihinde yayınladığ 1 "1 Numaralı Ordu Emirnamesi" ile de taarruz prensibine yeni bir boyut getirdi. Bu emirname ile ordunun ateş gücünün artırılmasının önemi ortaya konulmuş, karşı taraf üzerinde karma sınıfların ateş üstünlüğünün süratli bir şekilde tesis edilmesi gerektiğini vurgulamıştır. Emirnamenin başlangıç bölümünde ise "komutanların savaş alanında bulunması ve komutanın bizzat cepheden yürütülmesi" emri veriliyordu. Bu husus öylesine işlenmişti ki, bunun etkileri sadece Birinci Dünya Savaşında değil, Türk Kurtuluş Hareketinde de görülecek, subaylar askerlerle birlikte hatta onların önünde muharebelere katılacaktır.

Osmanlı Birinci Dünya Savaşına girmeden önce 2 A ğustos 1914 tarihinde ittifak antlaşmasını imzalamış, bir gün sonra seferberlik ilan etmiştir. 4 Ağustos 1914 tarihinde Başkomutanlıktan verilen bir emirle, Doğu Anadolu'da Ruslara karşı III. Ordu müfettişliği Ordu Komutanlığı haline dönüştürüldü. 9, 10 ve 11. Kolordular ile İran sınırındaki Revanduz'da bulunan iki gönüllü kolordu ve Van'da bulunan bir jandarma tümeninden oluşan 3. Ordunun merkezi önce Erzincan, sonra Erzurum olmuş, komutanlığına Hasan İzzet Paşa, kurmay başkanlığına ise Alman Yarbay Felix Guse tayin edilmiştir. ${ }^{6}$

Osmanlı 29 Ekim 1914 tarihinde Karadeniz'deki baskına kadar savaşa girmeyerek tarafsızlığını korumuştur. Almanlardan alınan Goeben 11 Ağustos tarihinde boğazlardan girmiş, 27 Ekim tarihinde Karadeniz'e açılmıştır. ${ }^{7}$ Savaş gemisi 29 Ekim'de Sivastopol, Novorosisk ve 30 Ekim'de Odesa limanların bombalamış böylece Osmanlı Devleti savaşa girmiştir. ${ }^{8}$

Bu olaydan sonra Ruslar 1 Kasım 1914 tarihinde Narman ve Kaleboğazı istikametlerinden sınırı geçerek Erzurum'a doğru harekâta başladı. Bu durum Rus Orduları Başkomutanlığı tarafından Router haber ajansı vasıtasıyla yapılan resmi açıklamada: "Birliklerimiz Türk sınırını geçti ve Türk ileri karakollarının gerilerine kadar uzandı. Bu harekât ve çatışmalar sonucunda Azap'a kadar olan bölge işgal edildi." şeklinde duyuruldu ve büyük bir başarı olarak gösterildi. Bu bölgelerin ele geçirilmesi Rusların kısa zamanda gösterdiği ilerlemeyi gösteriyordu. Artık Soğanlı Dağları ile birlikte bölgedeki Erzurum istikametine giden geçitlere Rusların hâkim olmaya başladıkları söylenebilirdi. Diğer taraftan zaten hazır bekleyen Ermeni çeteleri de Diyadin istikametinde ilerlediler. ${ }^{9}$

Aslında Rusların başlangıçta zayıf sınır birliklerini geri atarak ilerlemeleri onların gerçek gücünü göstermiyordu ve yanıltıcıydı. Köprüköy Türk Ordusu

\footnotetext{
${ }^{6}$ Arslan Tekin, Enver Paşa ve Dönemi, Kariyer Yayıncılık, İstanbul, 2016.

${ }^{7}$ Yavuz Özdemir, Bir Savaşın Bilinmeyen Öyküsü, Sarıkamış Harekâtı, Erzurum Kalkınma Vakfı Yayınları, Erzurum, 2003.s.21.

${ }^{8}$ Hasan Babacan, "Sarıkamış Harekâtına Talat Paşa'nın Yaklaşımı”, Zamansız Mahşer: Sarıkamış, Ed. Kars Valiliği Kültür Yayınları Dizisi, Kars, 2010.s.105.

${ }^{9}$ Hakkı Altınbilek ve Naci Kır, Birinci Dünya Harbinde Türk Harbi Kafkas Cephesi 3. Ordu Harekâtı, Cilt.1, Genelkurmay Basımevi, Ankara, 1993. s.101.
} 
tarafından son anda tahkim edilmişti. Köprüköy muharebeleri 6 Kasım 1914 tarihinde başladı. Başlangıçta Ruslar ilerlediler ancak ertesi gün kuvvetli bir Türk Birliği kaybedilen yerleri geri almak için taarruza başladı. Bu harekâtı duyuran The Times gazetesinin “Türk Ermenistan'ından gelen haberlere göre Ruslar Erzurum'un 33 mil doğusunda önemli bir mevziiyi ele geçirdiler."10 haberi bölgede ne görmek istediklerinin ortaya konması açısından oldukça ilginçti. Zaten, bundan sonra bu gazete Ruslar başarısız oldukça onlar hakkında tek bir kelime yazmayacaktır. 16 Kasımdaki Azap Muharebesinde Rus yenilgisi sonrasında da aynı gazete, " Ermenistan'da sert çatışmalar: Köprüköy ve Azap'ta Türklerle Ruslar arasında korkunç çatışmalar oldu. Türkler Ruslardan sadece birkaç top aldı." gibi olayı çarpıtan ve basite indirgeyen taraflı ifadeler kullaniyordu. ${ }^{11}$

Gerçekten de Ruslar bu muharebelerden sonra bir gerileme içine girmişlerdi. Osmanlı sınır birliklerinin fazla direniş göstermemesinden cesaret alarak hızla ilerleyen Rus ordusu 3. Ordu birliklerince Köprüköy’de başarılı bir savunma ile durdurulacak ve geri püskürtülecektir. 9 Kasım 1914 tarihli Genel Karargâh bildirisinde, “Türk Ordusunun Köprüköy bölgesinde kaybettiği mevzileri geri almak için taarruza geçtiği ve Rus ordusunun geri püskürtüldüğü" duyuruluyordu. ${ }^{12} \mathrm{Bu}$ habere göre Kafkas Cephesindeki muharebelerde Ruslar mağlup edilmiş, Türk süvarileri Kağızman üzerinden Ruslara taarruz ederken Rus ordu merkezine taarruz eden birlikler onları yenilgiye uğratarak eski mevzileri tekrar ele geçirmişlerdir. ${ }^{13}$

$\mathrm{Bu}$ döneme ilişkin verilen diğer haberlerde ise Rusların sınırı geçtikten ancak dört gün sonra kolbaşı ile Köprüköy'e gelebildikleri ancak burada aşiret süvari birliklerimizin taarruzları sonucu durduruldukları, süvarilerin "baba muharebesi" ile ilerleyişe mani oldukları, 29 Teşrin-i Evvel (11 Kasım 1914) günü kanlı muharebelerden sonra Köprüköy'ün süngü muharebeleriyle zapt edildiğini, bütün Rus kolordusunun firar eylediğini ve Türk kıtalarının düşmanı takibe başladığını bildiriyordu. ${ }^{14}$ İkdam gazetesinde "Erzurum'da Rus Esirleri" başlığıyla çıkan haber de ise "Köprüköy Muharebeleri sonrası Ruslardan çok miktarda makineli tüfek, erzak ve esirin ele geçirilerek Erzurum'a getirildiği ve Erzurumluların büyük gruplar halinde toplanarak kahraman askerleri dualarla karşıladıkları ve bu manzaranın ordunun moralini yükselttiği"nden bahsediyordu. Ahmet Cevdet Bey bu muharebe sonrası yayınladığ 1 makalesinde stratejik bir mevkide bulunan Köprüköy muharebelerinin

\footnotetext{
${ }^{10}$ The Times Gazetesi, November 9, 1914. No:40691.

${ }^{11}$ The Times Gazetesi, 18 and 21 November 1914.

12 İkdam Gazetesi, 23 Teşrin-i Evvel, 1330/5 Kasım 1914.

${ }^{13}$ İkdam Gazetesi, 27 Teşrin-i Evvel, 1330/9 Kasım 1914.

${ }^{14}$ Sabah Gazetesi, 31 Teşrin-i Evvel 1330, İkdam, 31 Teşrin-i Evvel 1330/ 13 Kasım 1914; Kemal Arı, Birinci Dünya Savaşı Kronolojisi, Ankara, 1997.s.67-75.
} 
Türklerin lehine sonuçlanmasıyla üstünlüğün Türklere geçtiğini söylüyordu. Bu başarıda, esir Rus askerlerinin de takdir ettiği şekilde, Türk topçu birlikleri de önemli rol oynamışlardır. ${ }^{15}$ Rusların Köprüköy ve Azap muharebelerinde yenilgiye uğratılması, Balkan Savaşlarındaki facialardan sonra Türk Ordusunun sevk ve idare yönünden geldiği önemli aşamaları açıkça ortaya koyuyordu. ${ }^{16}$ İstanbul'daki Alman askeri ataşesine göre büyük bir başarı ve zafer olarak nitelendiren bu harekâtta Ruslar büyük kayıplar vermişlerdir. Hatta Köprüköy ve Azap Muharebelerinden sonra Türk birlikleri Ağrı Tutak'da Ruslara karşı taarruz ederek, Rusları Tutak'tan geri çekilmeye de mecbur etmişlerdi. Köprüköy zaferi her açıdan Türklere büyük bir moral vermiş ve Enver Paşa 3. Ordunun taarruz edebilecek güce sahip olduğu kanaatini edinmiştir.

Rus ordusu bu harekâtta Ermenileri kışkırtarak yanına çekmişti. 9. Kolordu Kurmay Başkanı Şerif İlden hatıralarında, 1914 yılında savaşın başlamasıyla birlikte Beyazıt, Eleşkirt ve Pasinler sınırını geçen Ermenilerin Türk Ordusu aleyhine önemli faaliyetlerde bulunduğundan bahsetmektedir. ${ }^{17} \mathrm{Bu}$ ve bundan sonraki safhada Ermeniler, Osmanlı Ordusuna karşı casusluk, keşif, kılavuzluk, sabotaj, propaganda faaliyetleri yürütmüş, bunun yanında kurdukları gönüllü müfrezelerle doğrudan silahlı çatışmanın bir parçası olmuşlardır. Aslında Ermeniler Ruslar tarafından açıkça kullanılmışlar daha doğrusu bazı Ermeni grupları böyle bir kullanılmayı gönüllü olarak kabul etmişlerdir. Bu haliyle de sadece bu harekâtın değil aynı zamanda bundan sonraki Türk Ermeni ilişkilerinin geleceğini belirlemişlerdir. Erzurum ve Beyazıt Ermenileri daha seferberliğin ilk günlerinde silah ve cephaneleriyle Rusya'ya kaçarak çetelere katılmıştır. Kayıtlara göre 23 Ekim 1914 tarihinde sadece Kağızman'da Osmanlı uyruğunda 8.000 Ermeni asker kaçağı bulunuyordu. ${ }^{18}$ Ermeniler ayrıca yoğun biçimde Türk askerlerinin moralini bozmaya çalıştılar, Türk askerini askerden kaçırmak için propaganda yaptılar. ${ }^{19}$

Rusya'ya kaçan Ermenilerden beş çete grubu oluşturularak silahlandırılmış ve Osmanlı Ordusunu arkadan vurmakla görevlendirilmişlerdi. Ermeni yazar Antranik, bu gruplardan 1.200 kişilik bir çetenin İran sınırından 3 Kasım 1914 tarihinde, ikinci grubun ise 24 Ekim tarihinde Iğdır'dan içeri sızdırıldığından, 500 kişilik bir grubun 1 Kasım'da Sarıkamış'a, 500'er kişilik iki ayrı grubun ise Erzurum ve Van'a gönderildiğinden ve bu gruplara Rus hükümeti tarafından

\footnotetext{
15 İkdam Gazetesi, 6 Teşrin-i Sani 1330/19 Kasım 1914.

${ }^{16}$ Von Liman Sanders, Türkiye'de 5 Yıl, İstanbul, 1968.s.54-55.

${ }^{17}$ Köprülülü Şerif İlden, Sarıkamış, Yay. Haz. Sami Önal, İş Bankası Yayınları, İstanbul, 1998, s.112.

${ }^{18}$ Necdet Sevinç, Arşiv Belgeleriyle Tehcir, Ermeni İddiaları ve Gerçekler, Avrasya-Bir Vakfi Yayınlar1, 2003, s.108.

${ }^{19}$ Necla Basgün, Türk-Ermeni İlişkileri, Abdülhamit Cülusundan Zamanımıza Kadar, San. Matbaası, Ankara, 1970.s.63.
} 
para yardımında bulunulduğundan bahsetmektedir. ${ }^{20}$ Bir İngiliz diplomat ise 7 Kasım 1914 tarihinde ülkesine gönderdiği raporda, 60.000 gönüllü Ermeni'nin Kafkas sınırında Türklere karşı savaşmak üzere beklediğini bildiriyordu. ${ }^{21}$ Ruslar bölgedeki Ermenileri ayaklandırmaya yönelik planlamasını 1914 yılı sonbahar ayları boyunca devam ettirmiştir. Rus Konsolosu Adamov konuyla ilgili vermiş olduğu bir raporda, “Sadece Erzurum'un Ermeni ahalisi değil Erzincan, Sivas ve Kayseri dâhil olmak üzere çevredeki bütün kentler Rus birliklerinin gelişini sabırsızlıkla bekliyor." diyordu.

Diğer taraftan Erzurum bölgesindeki aşiretlerin büyük çoğunluğu Osmanlıya sadık kalmış, Karayazı ve Hınıs ve Tekman gibi bölgelerde atlı aşiret alayları kurarak Ruslara karşı kahramanca mücadele etmişlerdir. Bu aşiretlerin Osmanlı Devleti yanındaki mücadeleleri ve topraklarını koruma çabaları oldukça önemliydi. Bu köylerden birisi de Horasan ilçesinden Ağrı'ya giderken 50 kilometre uzaklıktaki Iğırbığır Köyüdür.22 Köy 93 Harbinde (1877-1878) ve sonrasında Ruslara karşı mücadele etmiş ve asla devlete karşı bir hareket içinde olmamışlardır. ${ }^{23}$ Bu yüzden Ruslar burayı ele geçirdiğinde Konya'ya kadar göç etmek zorunda kalmışlardır. Ruslara karşı mücadeleleri dolayısıyla Sultan 2. Abdülhamit tarafından bu aşirete Alaylık madalyası verilmiş, madalya Erzincan'da aşiretin başındaki Hasan Bey tarafından Ahmet Muhtar Paşa'nın elinden alınmıştı. ${ }^{24}$ Bölge halkı Ruslara karşı aynı direnci Birinci Dünya Savaşında da göstermişler, düzenli askerlerle birlikte kahramanca mücadele etmişlerdir.

Padişah Sultan Reşat'ın savaş emri ile 11 Kasım 1914 tarihinde tüm İslam dünyasının Osmanlı bayrağı altında ortak düşmanlarına karşı Cihat Fetvası yayınlanmıştır. Osmanlı daha savaş ihtimalinin belirmesiyle bir milyon kişiyi askere çağırmış ancak bu sayının üçte birini o da Almanların desteği ile silahlandırabilmiştir. Ekonomi de yine Alman desteği ile ayağa kaldırılmaya çalışılmış ancak başarılı olunamamıştır. Anadolu'nun ortasından doğuya giden demiryolu şebekesi olmadığı gibi Karadeniz de Rus donanmasının üstünlüğü kırılamamıştır. Kasım ayı gibi elverişsiz kış koşullarının yaşandığı bir dönemde Rusların saldırılarına karşı mücadele ediliyordu. ${ }^{25}$

Osmanlılar açısından bölgeye ulaşan ikmal yollarının yetersizliği gerçekten büyük bir sorundu. Bu noktada 3. Orduya silah, erzak ve cephane götüren Bezmi-Alem ve Mithat Paşa vapurlarının 6-7 Kasım 1914 tarihinde batmış

\footnotetext{
${ }^{20}$ Muammer Demirel, Sarıkamış’ta Ermeni Olayları, Atatürk Üniversitesi Türkiyat Araştırmaları Enstitüsü Dergisi, 13 (31),2006.s.108.

${ }^{21}$ British Document on Armenians, FO, 371/2146, No: 68443, 7 November 2014.

${ }^{22}$ Köyü Bingöl'den ayrılıp buralara gelen iki kardeşin kurduğu söylenir.

${ }^{23}$ A.S. Servet Horasan, Iğırbığır Köyü ve Cibo Aşireti, Ümit Matbaacılık, İstanbul, 2009.s.20.

${ }^{24}$ Osmanlı Arşivleri, 19/7/1335 tarihli Erzurum Harbiye Nezareti Telgraf 2714.

${ }^{25}$ Enver Tekin, İmparatorluğun Son Kurşunu Enver, Yakın Plan Yayınları, İstanbul, 2017.s.124.
} 
olmaları önemlidir. Bu sorun halkın desteğiyle aşılmış ve bu batıştan bir hafta sonra gıda, benzin, araç ve cephane bulunan üç vapur dolusu malzeme 3 . Orduya halk tarafından ulaştırılmıştır. ${ }^{26}$ Orduya ikmal desteği sağlanması ile ilgili bölge halkının özellikle Erzurumluların desteği olağanüstüydü. Köprüköy ve Azap Muharebelerinin devam ettiği günlerde Ordu Komutanı Hasan İzzet Paşa Erzurum Valisi Tahsin Bey'i arayarak muharebelerin gerçekleştiği yerlere acil erzak nakli yapılmasını istemiştir. 9. Kolordu Kurmay Başkanı Yarbay Şerif (İlden) hatıralarında, "Taarruza geçeceğimiz söylendiğinde heyecanlandık. Her tümen cephe gerisinde küçük ölçekte gece hücum eğitimi yaptırmaya başladık. Topçu ve piyade cephanesi Trabzon ve Bayburt'a kadar gelmişti. Halk canla başla orduyu destekliyor, kışın şiddetine rağmen kadın ve çocuklar güle oynaya sırtlarında ve kuşaklarında fedakârca cephane taşıyor, fanila çorap ve çamaşırlar Erzurumlular tarafından orduya armağan ediliyordu. Halkın bu desteği orduya neşe ve sağlamlık verdi." derken, Albay Aziz Semih (Ilter) ise "11. Kolordu, erzak kalmadığından feryat ediyor. Erzurum valisi 150.000 kilo erzakı taşımayı üzerine aldı. Erzurum ahalisi vatan sevgisiyle bunları taşımayı seve seve kabul ettiler. Otuz kiloluk çuvalları mektep çocukları hükümet konağı önünden taşımaya başladığından herkes ağlıyordu." diyerek Erzurum halkının bu savaşlar esnasındaki özveri ve üstün niteliklerini tarihe not düşüyordu. ${ }^{27}$ Gerçekten de bu tarihte Türklerin elinde ne yeterli insan gücü, ne silah fabrikaları, ne de yeterli ulaşım şebekesi ile orduyu destekleyecek erzak stokları vardı. Elde sadece vatanlarına aşk derecesinde bağlı insanlar bulunuyordu. Dağılan kuvvetler yaya yürüyüşle Erzurum civarında toplanmaya çalışılmıştır. ${ }^{28}$ Türklerin elinde her türlü meşakkate, yokluğa katlanan değerli bir insan malzemesi vardı ve bu savaşların kazanılmasında çok önemliydi.

1877-1878 Osmanlı Rus Harbinden sonra yapılan Berlin Antlaşması gereği Ruslar Erzurum'dan çekilmiş ancak Kars, Ardahan, Artvin, Batum, Sarıkamış ve Oltu Ruslarda kalmıştı. Erzurum bölgesinde yer alan Aras, Çoruh ve Fırat Vadileri Anadolu içlerine açılım sağlaması bakımından askeri açıdan çok önemlidir. Doğudan Ardahan, Kars ve Ağrı'dan gelen istikametler Erzurum'da

\footnotetext{
${ }^{26}$ Murat Bardakçı Hafız Hakkı Paşa. Sarıkamıș Günlüğü, , İș Bankası Yayınları, Ankara, 2016. s.49.

${ }^{27}$ Çocukların cepheye malzeme taşıması daha sonraları bazı sinema filmlerine de konu olacaktır. Ancak olayın geçtiği yer konusunda değişik anlatılar mevcuttur. Murat saraçoğlu ve Özhan Eren'in yönettiği, "Karlara yazılmış gerçek bir destan, 120" isimli film,1914 yılında Van'da savaşa kurban verilen gencecik insanların trajedisini beyaz perdeye yansıtmayı amaçlamıştır. Senaryoya göre 1914 yılında Rusların Erzurum'a saldırmalarıyla Van'daki Jandarma Tümeni Türk birliklerine destek vermek için yola koyulur. Çarpışmalar yoğunlaşır ve cephane tükenir. Birilerinin askerlere cephane götürmesi gerekir. Ancak herkes cephededir. $\mathrm{O}$ anda 12-17 yaş arası çocuk bu taşıma işine gönüllü olur ve karlı yollarda sırtlarındaki cephaneleri ile günlerce sürecek bir yolculuğa çıkarlar. Aynı olay Mart 2007 tarihinde Kültür Bakanlığından izin alınarak yayınlanan “Erzurum'un Gönül Sultanları” isimli kitabın 177. Sayfasında Erzurum'da gerçekleşmiş olarak anlatılmaktadır. Albay Semih İlter'in hatıralarında bu konu açıkça bahsedilmektedir. Buna göre Erzurum'da böyle bir olay gerçekleşmiştir. Van'da da benzer bir olay gerçekleşmiş olabilir.

${ }^{28}$ Şevket Süreyya Aydemir, Tek Adam, Remzi Yayınları, İstanbul, 1997, s.96-99.
} 
birleşir. Bu nedenle tarih boyunda kilit olma rolünü muhafaza etmiştir. Birinci Dünya Savaşının başında 29-30 Ekim 1914 tarihinde Yavuz ve Midilli savaş gemilerinin Rus limanların bombalamasından sonra Kafkaslarda bulunan Rus Ordusu 1 Kasım 1914 tarihinde sınırı geçerek Erzurum'a doğru ilerlemeye başlamıştı. Köprüköy Savaşları; 1 Kasım 1914 yılında Rusların Sarıkamış'tan 60 kilometre ilerleyerek Horasan'1, daha sonra oradan da 40 kilometre daha ilerleyerek Köprüköy'ü ele geçirmeleri sonucu başlamıştır. Ruslar Köprüköy'ü ele geçirdikten sonra 3. Ordu Karargâhının bulunduğu Pasinler'deki Üğümü (Bu köy 1048 yılında Pasinler Zaferinin de kazanıldığı köydür) Köyüne doğru ilerlerken, "Kanlı Mevki" denilen yerde çok şiddetli bir muharebe ile durdurulmuştur. Ruslar bu savaşlarda kendi kayıtlarına göre mevcutlarının \%40'ını kaybetmişlerdir. Bu noktada Erzurum'dan Ağrı ve Kars'a giden anayol üzerinde bir anıt bulunmaktadır. Kanlı Mevki çok yüksek bir yer olmamasına rağmen, çevresinde göre durumundan dolayı hâkim bir konumdadır. Buradan bakılınca sadece Pasinler ilçesi ve ovası değil, açı havalarda Erzurum ili Palandöken Dağı zirvesindeki Ejder Tepesi bile gözükmektedir.

28 Ekim 1914 tarihinde Karadeniz'de Rus gemi ve limanlarının bombalanmasının ardından 1 Kasımda zaten hazır bekleyen Ruslar saldırıya başlamıştır. İlk silah sesi ve saldırılar Doğu Beyazıt'tan gelmiştir. Bu tarihte Kars, Ardahan, Batum, Ardahan ve Sarıkamış zaten 1877-1878 Osmanlı Rus savaşından beri 37 yıldır Rusların elindeydi. Osmanlı Ordusu zaten bu tür bir saldırıyı bekliyordu. 3. Ordu Komutanı savaşın başlamasından önce yayınladığı emirde, "Rusların denizden 29 Ekimde taarruz ettiğini ve artık karadan da taarruzlarının beklenmesini ve bu doğrultuda harekâta hazır olunması"nı bildiriyordu. Bu tarihlerde Rus kuvvetlerinin sadece yüzde üçüne karşıllık gelen kısmı Kafkaslarda bulunmakta olup kalan tüm kuvvetleri Almanya'ya karşı konuşlanmıştı. Buradaki kuvvetlerin Kafkas cephesine derhal aktarılması mümkün değildi. Türk III. Ordusunun mevcudu 118.000, Rus Ordusunun ise 100 bin civarındaydı. Türk Ordusunun savunmada kalma yerine taarruza karar vermesindeki önemli etkenlerden birisi de Rusların kuvvet çoğunluğunun bulunduğu Avrupa Cephesinde 26-30 Ağustos 1914 tarihinde Tannenberg Muharebelerinde yaşadığı hezimettir. ${ }^{29}$ Bu savaşta Ruslar Almanlar tarafından kuşatılmıs ve 125 bin Rus askeri daha savaşın başında esir alınarak kesin bir yenilgiye uğratılmışlardır. Bu harekâttaki Rus yenilgisi sadece Osmanlının savaşa girmesinde bir etken olarak kalmamış aynı zamanda Köprüköy’de taarruz yapılabileceği konusunda da ilham vermiştir.

Ruslar taarruza başlayınca Enver Paşa Rusların geriden takviye almasının mümkün olmadığını düşündüğünden İstanbul'dan 3. Orduya gönderilen emirde, "geniş bir cepheden ilerlemekte olan düşmanın üstün olmadığı ve ayrı

${ }^{29}$ www.britannica .com/Giriş Tarihi 30 Mayıs 2018. 
ayrı ilerleyen düşman kollarını ezmek gerektiği" belirtiliyordu. ${ }^{30} \mathrm{Bu}$ kararda Enver Paşa' nın Harbiye' den sınıf arkadaşı okulu birinci bitiren Hafız Hakkı'nın da etkisi vardı. Hafız Hakkı 3 Kasım 1914 tarihli günlügüüde,"Ordu fazla temkinli hareket ediyor. Düşman beş koldan hareket ediyor. Düşmanın cephesi geniş ve kuvvetleri zayıf. Saldırı ile zafer kazanılabilir, kovalanabilir, Azerbaycan istikametinde ilerlenebilir. Enver'e bu durumu iletim bir emir yazdırdım." şeklinde bahsetmektedir. ${ }^{31}$

Ancak Ordu Komutanı Hasan İzzet Paşa Rusların çok güçlü olduğunu düşünüyordu ve İstanbul'dan gelen emri tereddüt içinde uygulayarak Rusları takip etmekte yetersiz kalmış ve böylece Sarıkamış harekâtının başlangıcında önemli bir fırsatı kaçırmıştır. Türk Ordusu burada çekilen düşmanın durumunu iyi keşfedememiştir. Albay Şerif bu tereddüdü, “Düşmanın Aras havzasında bir tümen Narman civarında ise bir tugay çapında kuvvetleri varken anlayamamıştı. Hâlbuki 3. Ordu altı tümenden oluşuyordu." şeklinde açıklamıştır. ${ }^{32}$

Bu savaşlar esnasında Osmanlı Ordusunun komuta kademesi arasında tam bir eşgüdüm mevcut değildi. Birlikler kararsızlık içerisinde oradan oraya intikal ettirilerek gereksiz yere yorulmuştu. Örneğin bu harekâtta Bağdat'tan Kafkas cephesine yürüyerek gelen 37. Tümen ilk muharebelerde başarılı olamadığı gibi sonrakilerde de bir varlık gösterememiştir. Ancak küçük rütbeli personel ve askerler başarılı olmak ve kendilerini göstermek için olağanüstü bir çaba sarf ediyordu. Muharebelerin başlangıcında Türk Birlikleri bir bocalama geçirmiş ancak birlik komutanlarının üstün cesaretleri ve kahramanlıkları sonucu kısa sürede toparlanarak karşı taarruza başlamıştır.

\footnotetext{
${ }^{30}$ Ziya Nur Aksun. Enver Paşa ve Sarıkamış Harekatı, Ötüken Yayınları, 2005.s.210.

${ }^{31}$ Bardakçı, Hafız Hakkı Paşa'nın Sarıkamış Günlüğü, s.43.

${ }^{32}$ Aksun, Enver Paşa ve Sarıkamış Harekatı, s.198.
} 


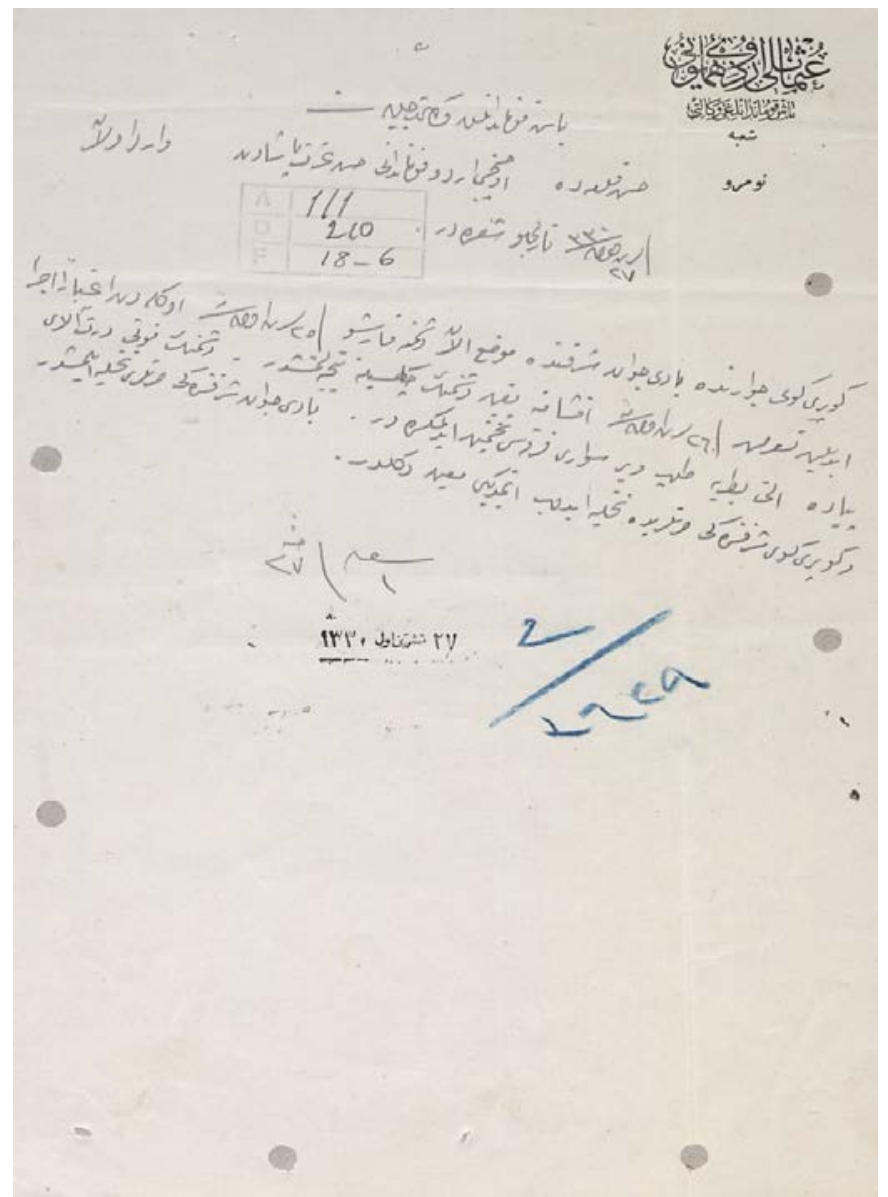

BDH-Klasör Nu-139 Dosya Nu-638 Fihrist Nu-18-6

Köprüköy civarında mevzii alan düşmana karşı 07 Kasım 1914 tarihinde öğleden itibaren icra edilen taarruzun 08 Kasım 1914 akşama yakın düşmanın çekilmesiyle neticelendiğine dair 3'üncü Ordu Kumandanlığı tarafından Başkumandanlık Vekâleti'ne gönderilen 09 Kasım 1914 tarihli rapor.

Kanlı Tepenin ele geçirilmesinden sonra da ileri harekâtına devam eden Türk Ordusu ardından Köprüköy'ü de ele geçirmiştir. 


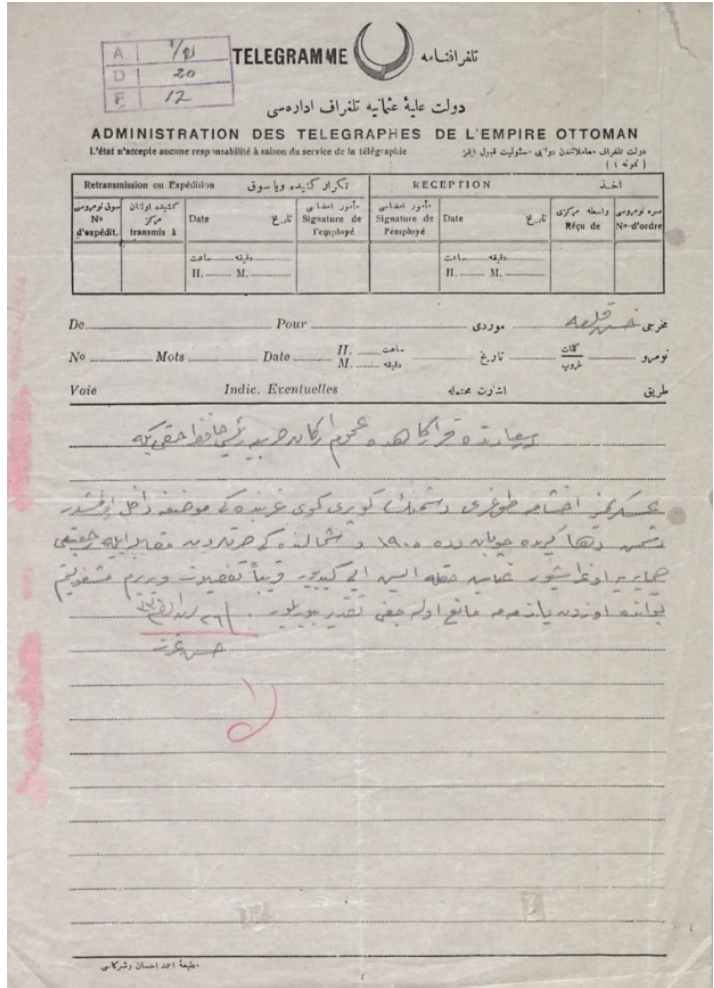

BDH-Klasör Nu-140 Dosya Nu-642 Fihrist Nu-17

Düşmanın Köprüköy batısındaki mevziiye dâhil olduğu, düşmanın daha geride Çobandede, 1950 rakımlı tepe ve kuzeyindeki sırtlardan mukabele ile geriye kaçışını himayeye uğraştığına dair 07 Kasım 1914 tarihli rapor.

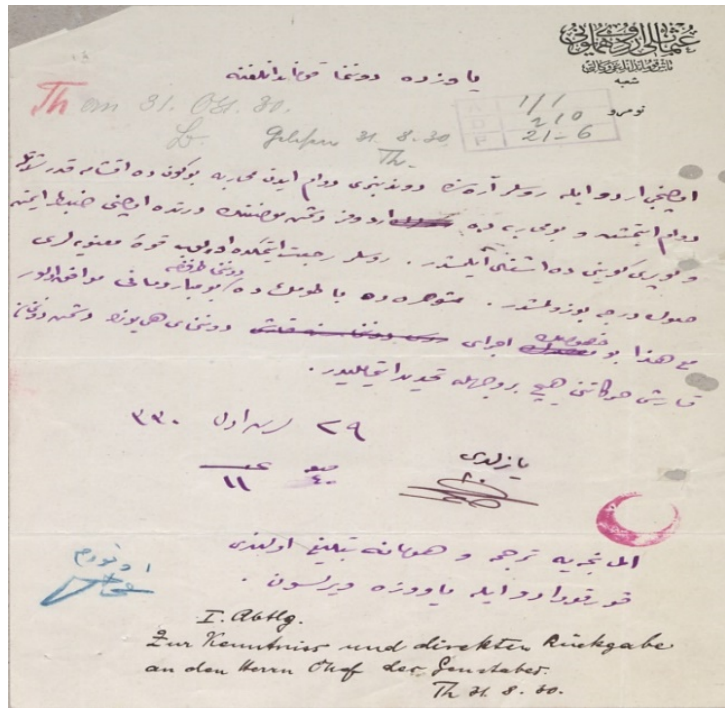

\section{BDH-Klasör Nu-139 Dosya Nu-638 Fihrist Nu-21-6}

3’üncü Ordu ile Ruslar arasında devam eden muharebenin 11 Kasım 1914 tarihi akşamına kadar devam ettiği, Ordu'nun, düşmanın mevzilerinin dörtte 
üçünü zapt ettiği, Köprüköyü'nü de işgal ettiğine dair gönderilen 11 Kasım 1914 tarihli rapor.

Sarıkamış Harekâtına 9. Kolordu Kurmay Başkanı olarak katılan İlden Köprüköy Savaşlarını şu şekilde değerlendirmektedir. Aslında Köprüköy Savaşları öncesi bir karışıklık ve bilinmezlik ortamı söz konusuydu. Savaşın üçüncü günü bile Hasankale'de (Pasinler) neler olduğunu bilmiyorduk. Erzurum'a gelen bir yolcu bize şu açıklamada bulundu. “İlk günlerde çok savaşlar oldu. Bizimkiler başlangıçta bozgun verdi. Ben kaleden gözlüyordum. Sonra Paşam Allah başımızdan eksik etmesin sizin gibi komutanlar, subaylar kılıçla, tabancayla bozulan askerin önüne geçtiler ve hepsini durdurdular" ${ }^{\prime 3} \mathrm{Bu}$ noktada Albay Ziya Yergök komutasındaki alayın cesaretle ileri atılması ile moral bulan birlikler hep birlikte taarruza kalkarak düşmanı Köprüköy'deki mevzilerinden atmaya muktedir olmuşlardır.

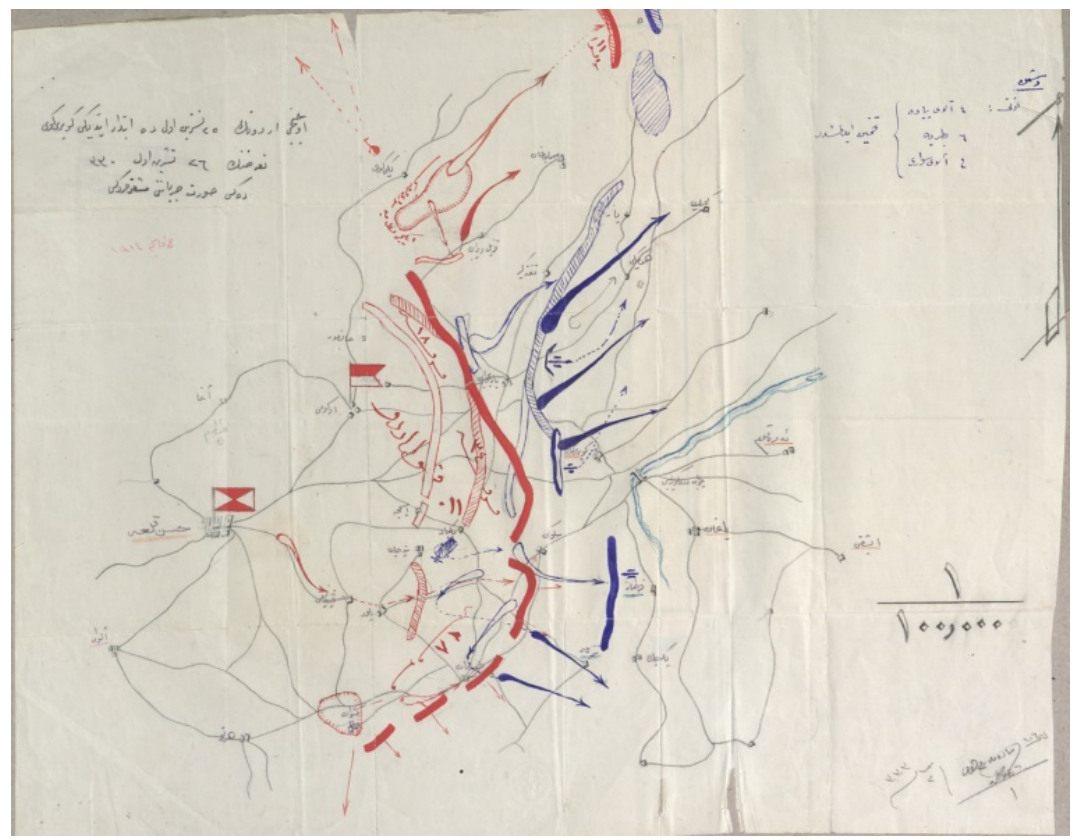

BDH-Klasör Nu-2950 Dosya Nu-H6 Fihrist Nu-1-74

3'üncü Ordu'nun 08 Kasım 1914 tarihindeki (Köprüköy Muharebesi) durumunu gösterir kroki.

33 İlden, Sarıkamış, Yay. Haz. Sami Önal, s.112. 


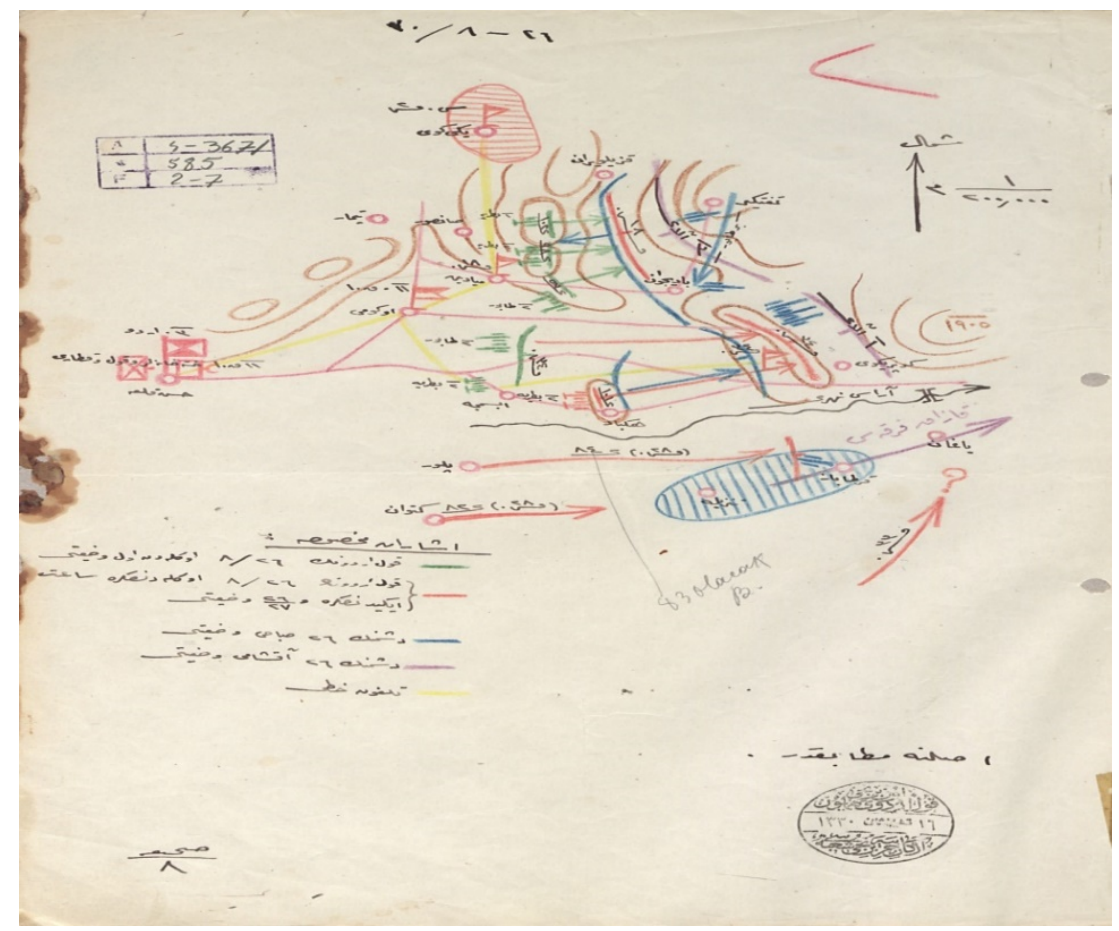

BDH-Klasör Nu-2858 Dosya Nu-224 Fihrist Nu-2-7

11'inci Kolordu'nun ve düşmanın 08-09 Kasım 1914 tarihindeki vaziyetini gösterir kroki.

Türk subayı ve askerinin büyük bir özverileri ve kahramanlıkları bu başarıyı getirmişti.

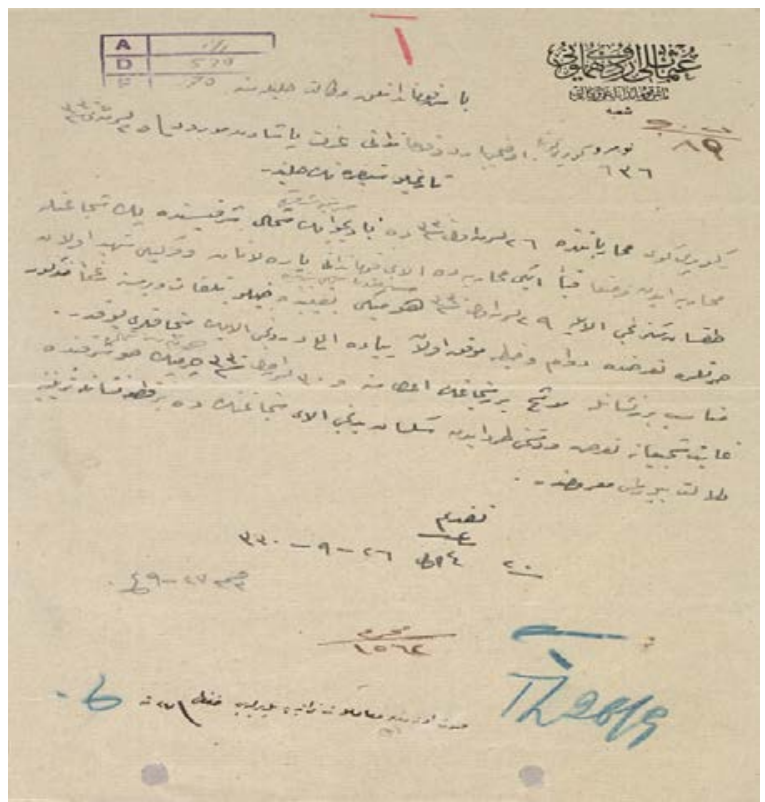

BDH-Klasör Nu-138 Dosya Nu-633 Fihrist Nu-70 
Köprüköy Muharebesi'nde çok büyük fedakârlıkla savaşan ve kahramanlık gösteren 98'inci, 54'üncü Alay'a nişan ve sancak verilmesi aynı şekilde büyük fedakârlık gösteren 87'nci Alayın sancağına nişan takılması için izin verilmesine dair 3'üncü Ordu Komutanı'nın 08 Aralık 1914 tarihli yazısı.

Ruslar bu muharebeler esnasında ağır kayıplar vererek Horasan ilçesi girişindeki Azap Köyüne kadar geri çekilmek zorunda kalmışlardır. Albay Ziya Yergök bu savaşı şöyle anlatır: Düşman kuvvetleri dağılmış ve Horasan önlerine kadar püskürtülmüşlerdir. Askerimiz: "Allaha şükürler olsun ilk defa Rus Askerini ensesinden seyretme imkânını bize bahşetti diyerek moral bulmuştur". ${ }^{34}$ Köprüköy Savaşları göstermiştir ki, Ruslar esaslı biçimde tehdit edilmeden bile tehlike altına girmemek için mevzileri terk edip çekiliyor. ${ }^{35}$

Gerçekten de Ruslar Türk Ordusunun taarruz gücü olduğunu tahmin etmiyorlard1 ve bu nedenle tedbirsiz hareket ederek tamamen kuşatılma tehlikesi ile karşı karşıya gelmişlerdi. Bu savaşın öncesinde siyasi ve askeri yetersizlikler ve ihmalkârlık yüzünden yaşanan Balkan Bozgunundan sonra Osmanlı Ordusunda yapılan düzenlemeler kapsamında komuta kademesi gençleştirilmiş, teçhizat gözden geçirilmiş, eğitim yöntemleri gözden geçirilmişti. Bu suretle Balkan Savaşında bozguna uğrayan ordu, kış şartlarında Rus Ordusuna gece taarruzları yapabilecek duruma gelebilmiştir. Ordudaki askerler ve genç rütbeliler başarılı olmak adına her türlü fedakârlığı yapmaya hazır durumdaydı. Bu harekâtta düzenli ordu birlikleri cesaret ve itaat hissi ile savaştılar. Özellikle subaylar Balkan Savaşlarının kaybının kendi üzerlerinde bıraktığı lekeyi temizlemek için canla başla çarpıştılar. ${ }^{36}$ Sonuçta subay zayiatı olması gerekenden daha yüksek gerçekleşti.

\footnotetext{
${ }^{34}$ Ziya Yergök, Sarıkamış'tan Esarete, Yay.Haz.Sami Önal, Remzi Kitabevi, İstanbul, 2005. s.36.

35 İlden, Sarıkamış, Yay. Haz. Sami Önal, s.101.

${ }^{36}$ Edward J. Erickson ve Mesut Uyar, Osmanlı Askeri Tarihi, İş Bankası Kültür Yayınları, İstanbul, 2014.s.490
} 


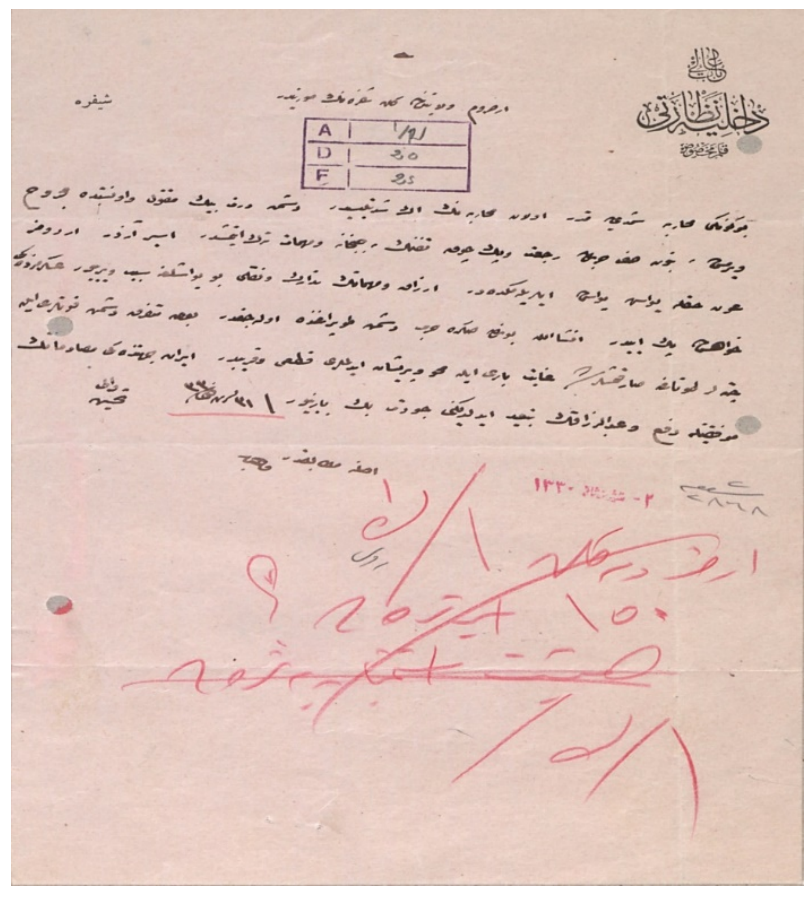

BDH-Klasör Nu-140 Dosya Nu-642 Fihrist Nu-25

13 Kasım 1914 tarihinde olan muharebenin şimdiye kadar olan muharebenin en şiddetlisi olduğu, düşmanın dört bin maktul ve o kadar yaralı verdiğine dair rapor.

Taarruz kesintisiz devam ettirilse Rusların toparlanmaları oldukça güç olacaktı. Ancak İstanbul'dan gelen "taarruza devam edin" emrine rağmen Ordu Komutanı Hasan İzzet Paşa Rusların bu kaçışını bir tuzak olarak değerlendirip, diğer komutanlar ve bölge valilerinin tepki göstermesine rağmen, birlikleri önce durdurmuş, sonra da orduyu on kilometre kadar geriye çekmiştir. Bu durum ise Rusların tekrar toparlanmasına imkân sağlamış ve bu nedenle daha sonraki Sarıkamış Harekâtı yapılmak zorunda kalınmıştır. Hasan İzzet Paşanın verdiği bu karar karşısında herkes şaşkındı. 9. Kolordu Kurmay Başkanı Şerif Köprülü de, geri çekilmenin güveni sarstığını ve taarruza kalkan ordunun geri çekilme emri verilmesiyle tüm ruhsal direncinin gevşediğini düşünüyordu. ${ }^{37}$

Gerçekte Rus Ordusu hesapsız bir ilerleme ile büyük bir hata yapmıştı. Rus Genelkurmayı, Osmanlı Ordusunu ciddi bir tehdit olarak görmediğinden, Kafkasları büyük ölçüde ihmal etmiş ve geride sadece bir kolordu bırakarak bölgede konuşlu düzenli ordu birliklerinin çoğunu Polonya'ya sevk etmişti. ${ }^{38}$ Ruslar kuvvetlerinin neredeyse \%97'sini Avrupa'da Almanlara karş1 sevk etmişlerdi. Bu durumda Doğu cephesinde büyük bir boşluk manasına

\footnotetext{
${ }^{37}$ İlden, Sarıkamış, Yay. Haz. Sami Önal, s.151.

38 Maslosvki E. V., General Maslofski'nin Umum Harpte Kafkas Cephesi Eserinin Tenkidi, Genelkurmay Basımevi, 1935, Ankara.s.23.
} 
geliyordu. Ortaya çıkan bu kuvvet boşluğunu doldurmak için acele yeni bir ihtiyat kolordusu teşkil edilmeye başlandı. Bu koşullar altında stratejik savunmada kalınması planlanmıştı. Ancak savaş başlar başlamaz sınırın Osmanlı tarafında kalan yüksek arazi kesiminin ele geçirilmesine karar verilmişti. 4 Kasım 1914 tarihinde yapılan taarruzla bu hedeflere ulaşıldı. Osmanlı hudut birliklerinin Rus ilerleyişi başlar başlamaz süratli bir şekilde geri çekilmesi, atılganlığıyla meşhur Rus General Georgy Bergman (Rus I. Kafkas Kolordu Komutanı) tarafından ciddi bir fırsat olarak algılandığından Ruslar planlara uymayıp ilerleyişe devam etmişlerdi. (Köprüköy Muharebelerini Ruslar Bergman Operasyonu diye isimlendirirler.) Bu esnada Enver Paşa'nın ikazı sonucu isteksiz bir şekilde harekete geçen III. Ordu Komutanı Hasan İzzet Paşa, zayıf Rus birliklerine 6 Kasım'da Köprüköy'de karşı taarruz icra ederek, sadece onları durdurmakla kalmadı Bergman'ı büyük bir yenilgiye uğrattı. Bu savaşlara Sıhhiye Onbaşısı olarak katılan Ali Rıza Etinin savaşa ilişkin anilarında; ${ }^{39}$

“4 Kasım Perşembe: Hasankale’de köylüler göç halinde. Hasankale yağma edilmiş durumda. Artık harp bütün şiddeti ile başladı. Yollar fena, bataklık. Ŭ̆raşa uğraşa ilerliyoruz. Aşă̆ı Pasin Ovasının sonunda Köprüköy civarında düşmanla harbe tutuşmuş, toplar atılıyor. Bir kurşun yağmuru başladr. Ayakta durmak mümkün değil. 2. Bölükten Arapgirli Hasan geldi. Zavall hem ayağından, hem de ăgzından vurulmuş. Yine de "Silahımı verin düşman üzerine gideceğim" diye bağırıyor. Harp bütün şiddeti ile devam ediyor. Bu esnada Bayburt Firkası geldi. Durup güzel bir dua ettiler. Doldur kapa komutunun ardında "harp" diye bağırıp kaputların çıkarıp harbe atıldılar. Maşallah aslan gibi askerler. Bunlar hücum edince düşmanı yerinden söktüler."

Diyor ve devaminda;

“Türk Ordusunun taarruzları Köprüköy'den sonra durmamış devam ediyordu. Askerler canla başla mücadeleye devam ediyordu. $12 \mathrm{Kasım}$ Perşembe saat on birde süngü tak emri verildi. Düşman daha yanlarna varmadan firar ediyor ki, arkasindan kurşun yetişmiyor. Saat on ikide tepelerdeki Ruslardan eser kalmadr."

diyerek bu muharebeler esnasında fedakârlık ve kahramanlıklara tanıklık ediyordu. Günümüzde bu savaşa ait anıtın olduğu "Kanlı Mevkii" denilen bölgede Ruslara büyük zayiat verdirilmiş ve Horasan önlerindeki Azap Köyünün bulunduğu yere kadar geri çekilmek durumunda bırakılmışlardır.

Köprüköy'den sonra Azap Muharebelerindeki bu başarılar Türk Ordusu için büyük bir fırsat yaratmıştı ancak Ordu birlikleri bir bütün halinde

${ }^{39}$ Ali Rıza Eti, Bir Onbaşının Doğu Cephesi Günlüğü, Haz. Gönül Eti, Türkiye İş Bankası Yayınları, İstanbul, Ocak, 2016, s.36-49. 
kullanılmak yerine parça parça hareket ettiği için Rusların tamamen imha edilmesi fırsatı da kaçırıldı. ${ }^{40}$

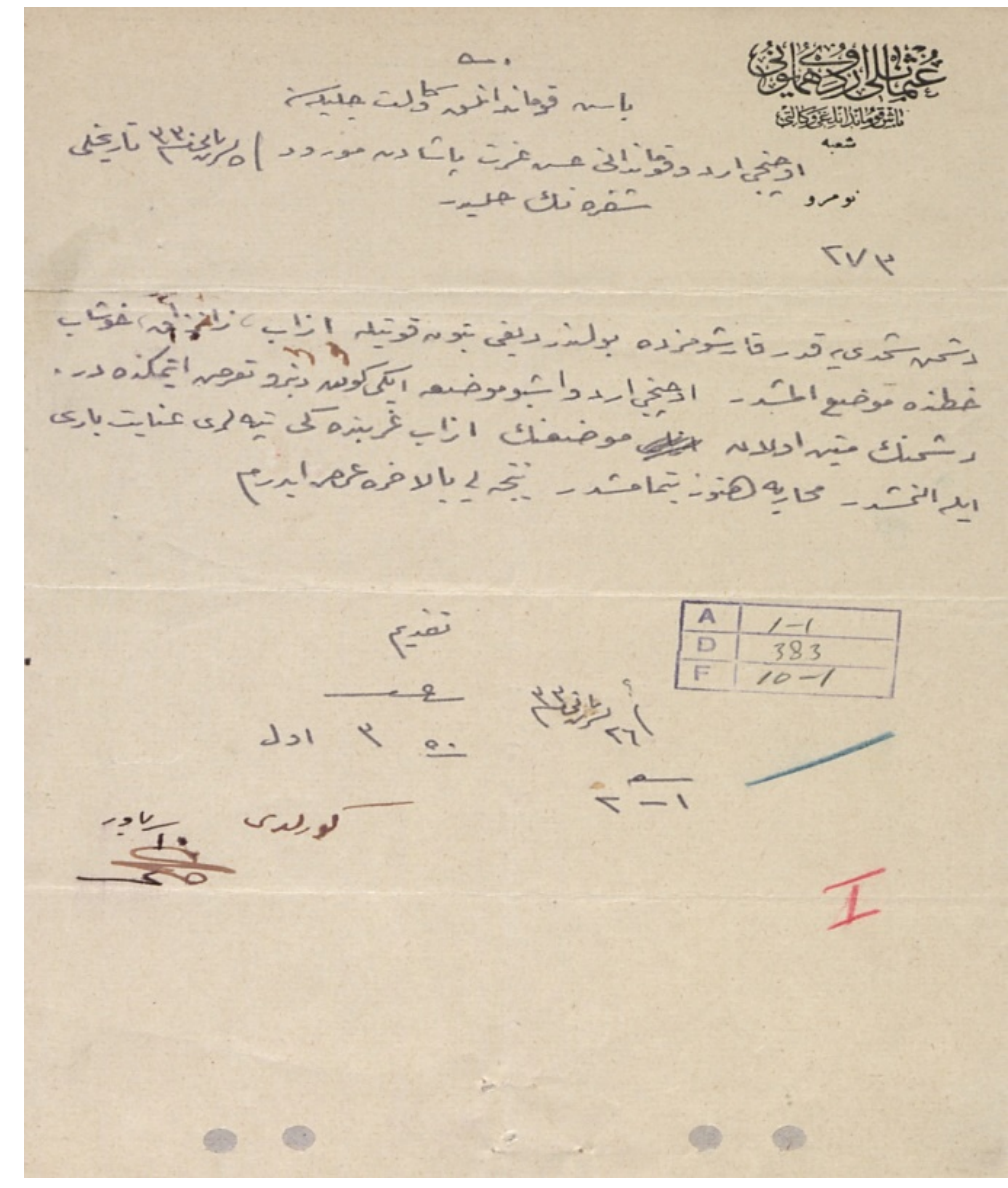

BDH-Klasör Nu-138 Dosya Nu-633A Fihrist Nu-10-1

Düşmanın bütün kuvvetinin Azap, Hoşap hattında mevzi aldığı, 3'üncü Ordu'nun bu mevziilere iki günden beri taarruz etmekte olduğu, Azap batısındaki tepelerin geri alındığına dair 3'üncü Ordu Kumandanlığı tarafından Başkumandanlık Vekâleti'ne gönderilen 18 Kasım 1914 tarihli rapor.

Kuvvetler bölünmeden ve kuşatma harekâtı tercih edilerek atılganlıkla kullanılabilse ve tereddüt edilerek 10 kilometre kadar geri çekilmese Rusların büyük bir yenilgiye daha uğratılıp tamamen imha edilmesi dahi mümkündü. Yine de bu zaferler Rusların bekledikleri kadar güçlü olmadığını ve yenilebileceğini göstermesi açısından Türkler için büyük moral kaynağı olmuştu.

${ }^{40}$ Maslosvki, General Maslofski’nin Umum Harpte Kafkas Cephesi Eserinin Tenkidi, s.53-58. 


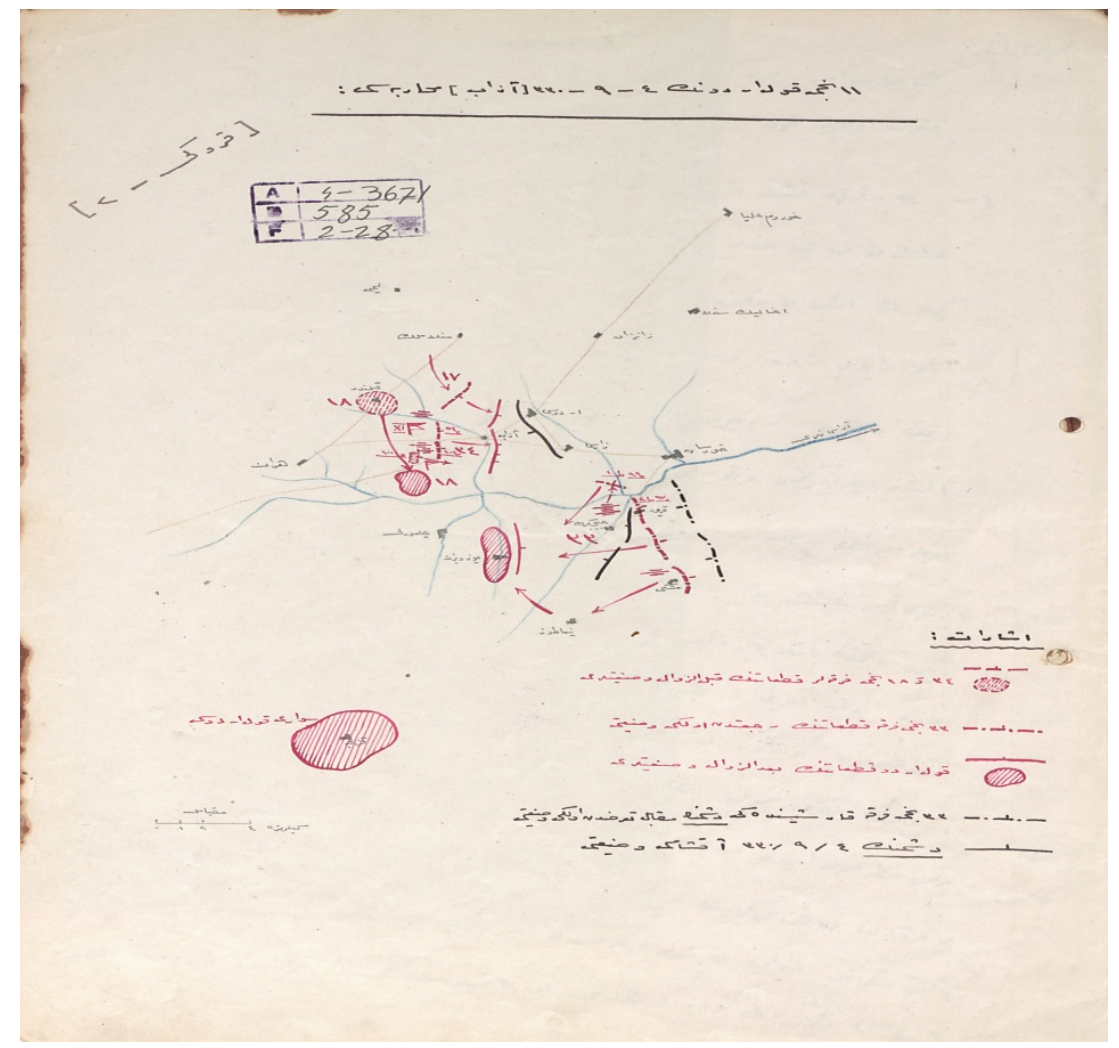

BDH-Klasör Nu-2858 Dosya Nu-224 Fihrist Nu-2-28.

11'inci Kolordu'nun 17 Kasım 1914 tarihinde yaptığ 1 Azap Muharebeleri'ne ait rapor ve krokiler.

Aslında Osmanlı yıkılırken bile güçlüydü. Yıllarca süren savaşa rağmen zaten var olan savaş kültürü giderek gelişmiş ve kaliteli bir komuta sınıfı oluşmuştur. Bu sınıf savaşmayı biliyordu ve sadece taktik alanda değil, stratejik alanda da uzmandi. ${ }^{41}$

Ancak bu muharebeler esnasında düşman hakkında bilgi toplama ve istihbarata dönüştürme işi taburdan başlayarak ordu seviyesine kadar yapılamadığı için lojistik açıdan ciddi sorunlar yaşandı. Diğer taraftan tecrübeli askerlerin gayretlerine rağmen emir komuta ve haberleşmede de sıkıntılar yaşand. Kumanda heyeti Ruslara son darbeyi vurmakta tereddüt ederken, aynı komuta heyeti Türk Ordusunu gereksiz yere yer değiştirmiş ve gece yürüyüşleri ile askerin enerjisini boşuna harcamıştır.

Diğer taraftan Köprüköy Muharebelerinde Ruslar hesapsız ilerlemiş ancak Türk taarruzları neticesi imha olacağını anlayınca geri çekilmişlerdir. Ancak bu olayı basit bir geri çekilme gibi göstermişlerdir. Olay Rus kayıtlarına göre şu şekilde anlatılmaktadır. 1914 yılında Kafkas Cephesinde ilk harekât Erzurum

${ }^{41}$ Alpar, Strateji ve Savaş Kültürünün Gelişimi, s.282. 
bölgesinde başladı. Rus Sarıkamış birliği 2 Kasımda sınıra gelmiş, 7 Kasımda ise Erzurum'a 50 kilometre mesafedeki Köprüköy mevzileri ele geçirilmişti. Bu durum karşısında Türk ordusu karşı harekâta başlamış, Ruslar kahramanca karşı koymasına rağmen sağ kanat kuşatma tehlikesine maruz kalınca Horasan'a çekilmek zorunda kaldılar. Türkler ilerlemelerine devam edince 14 Kasımdan itibaren büyük muharebeler olmuş ancak 19 Kasımdan itibaren Ruslar toparlanarak Türkleri savunmaya geçmek zorunda bıraktılar. Rus Ordusu 21 Kasımda genel karşı taarruza geçti ancak kışın bastırması nedeniyle Kafkas Ordusu taarruzu durdurarak yeniden savunmaya geçti. ${ }^{42}$ Başlangıçta zayıf sınır birliklerini geri atarak ilerlemeyi büyük bir başarı gibi duyuran Rusların, her iki muharebede de yenilerek geri çekilmesini basit bir cephe düzeltmesi gibi aktarmasının gerçeği tam olarak yansıtmadığ düşünülmektedir. Horasan gibi düz ve taarruz için uygun bir arazide Kasım ayında kışı bahane ederek ilerlemeyi durduran Rus Ordusu karşısında, kış şartları daha da zorlaşmışken, Türk Ordusu Aralık ayı sonralarında 3000 metreye yakın yükseklikteki dağlarda imkânsızlıklar içinde Sarıkamış Harekâtını gerçekleştirecektir.

Burada her ne kadar Türk Ordusu tarafından büyük bir zafer kazanılmasına rağmen bu durum yeterince değerlendirilememiş ve bu nedenle Sarıkamış Harekâtı yapılmak zorunda kalınmıştır. Azap Muharebeleri sonrasında 3. Ordu Komutanı Hasan İzzet Paşa'nın, Sarıkamış istikametine yapılacak bir taarruza karşı isteksiz davranması üzerine Enver Paşa beraberlerinde kurmay başkanı Bronsart con Schellendorf ve harekât şubesi müdürü von Feldmann olduğu halde 6 Aralık 1914'te Erzurum'a doğru yola çıktı. Enver Paşa 12 Aralık 1914 tarihinde Erzurum'a ulaştı. Hemen hemen aynı tarihlerde Rus Çarı da cephedeki morali bozuk askerlere moral vermek için Sarıkamış'a ve oradan sınıra gelmişti. Gelirken orman içine gizlenmiş bir Osmanlı keşif birliğinin önünden çok az bir koruma ile tehlikeli bir geçiş yapmış ve burada etkisiz hale getirilme veya esir edilme noktasına çok yaklaşmıştı. Ancak anlaşılmayacak bir nedenle otomobili ile geçen çarı gören keşif birliği "kendinizi belli etmeyin" emri gereği ateş açmamıştır. ${ }^{43}$ Eğer Rus çarı etkisiz hale getirilebilse belki de harekâtın seyri değişebilecekti. Hasan İzzet Paşanın Ordu komutanlığından istifade etmesi ile de bu görevi Enver Paşa'nın kendisi, kurmay başkanlığına Schellendorf, ikinci kurmay başkanlığına ise Albay Guse üslendi. Buna göre Sarıkamış'ta Rus ordusu yandan ve arkadan kuşatılacaktı ve ilk hedef Sarıkamış olacaktı. ${ }^{44}$

42 Şirokorad A.B., Rusların Gözünden Osmanlı-Rus Savaşları, Selenge Yayınları, İstanbul, 2013.s.491.

${ }^{43}$ Özhan Eren, Sarıkamış’a Giden Yol, Alfa Yayınları, İstanbul, Ekim 2005.s.356.

${ }^{44}$ Tekin, Enver Paşa Dönemi, s.364. 


\section{Sonuç}

Birinci Dünya Savaşının başlamasıyla birlikte 1977-1878 Osmanlı Rus Harbi sonrası ele geçirdiği Sarıkamış bölgesinden ileri harekâtla zayıf sınır birliklerini geri atarak önce Horasan, ardından Köprüköy istikametine ilerleyen Rus kuvvetlerini Türk III. Ordu birlikleri önce durdurmuş sonra da karşı taarruzla Köprüköy bölgesinden atarak Horasan'ın Azap Köyü bölgesine kadar atmıştır. Her ne kadar gerek sonrasında yaşanan Sarıkamış Faciası, gerekse savaşın kaybedenlerinin maksatlı olarak "Türk Zaferini" görmezden gelme çabaları ve yayınlarına rağmen Türk Ordusu Köprüköy Muharebelerinden sonra Azap Muharebelerinde de Rus ordusunu tereddüde yer bırakmayacak şekilde yenmiştir. Ancak Azap bölgesinde gerçekleşen muharebelerde Ordu Komutanı Hasan İzzet Paşa'nın kararsız davranışları, birlikleri bir bütün olarak ve süratle kullanmak yerine parça parça muharebeye sokması, yine manevra yaptırmak yerine fazla kayba neden olan cephe taarruzunu tercih etmesi nedeniyle Ruslara zaman kazandırmış, buna anlaşılmaz bir şekilde ordunun taarruzu durdurarak 10 kilometre kadar geri çekilmesi kararı da eklenince bu başarıdan yeterince yararlanılamamıştır. Her durumda o zamanın en güçlü ordularından birisi olan Rus Ordusu yenilgiye uğratılmış, geri çekilmek zorunda bırakılmıştır.

Bir harekâtta taarruz hızının sürdürülmesi yanında eğer taarruz eden çok güçlü değilse kuşatma manevralarını tercih eder. Cephe taarruzları ancak çok üstün kuvvetlere sahip olunduğunda tercih edilebilecek bir manevra şeklidir ve oldukça fazla kayba neden olur. Ancak iki gün süren Azap Muharebelerinde Osmanlı Ordusunun tümenleri daha önceki Köprüköy Muharebelerinin tersine, kuşatma taarruzu yerine, maliyeti ağır olan cephe taarruzları yaptı. Üstelik çatışmalar doruktayken, muharebe istihbaratının eksikliği nedeniyle paniğe kapılan İzzet Paşa taarruzu durdurarak yaklaşık 10 kilometre geri çekilme emrini verdi. Hâlbuki bu noktada Rus Ordusu komutanı Bergmann'da geri çekilmeye karar vermişti.

Bütün eksikliklerine rağmen Köprüköy ve Azap Zaferleri o dönemde dünyanın en güçlü orduları arasında bulunan Rus Ordusuna karşı kazanılmış büyük zaferler olarak tarihteki yerini almıştır. Zaferlerin kazandığı tarihler konusunda değişiklikler var ise de Köprüköy Zaferi 8 Kasım, Azap Zaferi için 16 Kasım 1914 tarihleri söylenebilir. Bu zaferlerin kazanılmasında bölge halkının fedakârlığının da büyük bir rolü olduğu bir gerçektir. Büyük fedakârlıklarla kazanılan bu zaferlerin ortaya çıkarılmasının ve gelecek kuşaklara aktarılmasının önemli olduğu düşünülmektedir.

\section{Kaynakça}

AKAD, Tanju Mehmet, Osmanlıların Stratejik Sorunları, Kastaş Yayınları, İstanbul, 2005. 
AKSUN, Ziya Nur, Enver Paşa ve Sarıkamış Harekatı, Ötüken Yayınları, 2005.

ALPAR, Güray, Strateji ve Savaş Kültürünün Gelişimi, Pelit Matbaası, Konya, 2015.

ALTINBILLEK, Hakkı ve Naci Kır, Birinci Dünya Harbinde Türk Harbi Kafkas Cephesi 3. Ordu Harekâtı, (Cilt.1), Ankara, 1993.

ARI, Kemal, Birinci Dünya Savaşı Kronolojisi, Ankara, 1997.

AYDEMIR, Şevket Süreyya, Tek Adam, Remzi Yayınları, İstanbul, 1997.

BABACAN, Hasan, "Sarıkamış Harekâtına Talat Paşa'nın Yaklaşımı", Zamansız Mahşer: Sarıkamış, (Ed. Kars Valiliği Kültür Yayınları Dizisi), Kars, 2010.

BARDAKÇI, Murat, Hafız Hakkı Paşa'nın Sarıkamış Günlüğü, İş Bankası Yayınları, Ankara, 2016.

BASGÜN, Necla, Türk-Ermeni İlişkileri, Abdülhamit Cülusundan Zamanımıza Kadar, San. Matbaası, Ankara, 1970.

British Document on Armenians, FO, 371/2146, No: 68443, 7 November 2014. DEMIREL, Muammer, Sarıkamış'ta Ermeni Olayları, Atatürk Üniversitesi Türkiyat Araştırmaları Enstitüsü Dergisi, 13/31, 2006.

EREN, Özhan, Sarıkamış'a Giden Yol, Alfa Yayınları, İstanbul, Ekim 2005.

ERICKSON, J. Eward, I. Dünya Savaşında Osmanlı Ordusu, Çev. Kerim

Bağrıaçık, Türkiye İş Bankası Yayınları, İstanbul, 2009.

ERİCKSON, J. Edward ve Mesut Uyar, Osmanlı Askeri Tarihi, İş Bankası Kültür Yayınları, İstanbul, 2014.

Genelkurmay Basımevi, Ankara, 1993.

ETİ, Ali Rıza, Bir Onbaşının Doğu Cephesi Günlüğü, Haz. Gönül Eti, Türkiye İş Bankası Yayınları, İstanbul, Ocak, 2016.

HORASAN, Servet A.S., Iğırbığır Köyü ve Cibo Aşireti, Ümit Matbaacılık, İstanbul, 2009.

İkdam Gazetesi, 23 Teşrin-i Evvel, 1330/5 Kasım 1914.

İkdam Gazetesi, 27 Teşrin-i Evvel, 1330/9 Kasım 1914

İkdam Gazetesi, 6 Teşrin-i Sani 1330/19 Kasım 1914.

İLDEN, Köprülü Şerif, Sarıkamış, Yay. Haz. Sami Önal, İş Bankası Yayınları, 4. Bask1, İstanbul, 1998.

KARABEKİR, Kazım, Hayatım, Yapı Kredi Yayınları, İstanbul, Mart 2017.

MASLOSVKI, E. V., General Maslofski'nin Umum Harpte Kafkas Cephesi

Eserinin Tenkidi, Genelkurmay Basımevi, 1935, Ankara.

Sabah Gazetesi, 31 Teşrin-i Evvel 1330, İkdam, 31 Teşrin-i Evvel 1330/ 13

Kasim 1914.

SANDERS, Von Liman, Türkiye'de 5 Yıl, İstanbul, 1968.

SEVINÇ, Necdet, Arşiv Belgeleriyle Tehcir, Ermeni İddiaları ve Gerçekler, Avrasya-Bir Vakfı Yayınları, Ankara, 2003. 
ŞİROKORAD, A.B., Rusların Gözünden Osmanlı-Rus Savaşları, Selenge Yayınları, İstanbul, 2013.

TEKİN, Arslan, Enver Paşa ve Dönemi, Kariyer Yayınc1lık, İstanbul, 2016.

TEKINN, Enver, İmparatorluğun Son Kurşunu Enver, Yakın Plan Yayınları, İstanbul, 2017.

The Times Gazetesi, November 9, 1914. No:40691.

The Times Gazetesi, 18 and 21 November 1914.

OSMANLI ARŞIVLERİ, 19/7/1335 tarihli Erzurum Harbiye Nezareti Telgraf 2714.

ÖZDEMIR, Yavuz, Bir Savaşın Bilinmeyen Öyküsü, Sarıkamış Harekâtı, Erzurum Kalkınma Vakfı Yayınları, Erzurum, 2003.

www.britannica .com/Giriş Tarihi 30 Mayıs 2018.

YERGÖK, Ziya, Sarıkamış'tan Esarete, (Yay.Haz.Sami Önal), Remzi Kitabevi, İstanbul, 2005. 